\title{
OBITUARIES
}

\section{Prof. E. J. Friedmann}

Prof. Ernst Josef Friedmann died in Cambridge on July 19 at the age of seventy-eight; he was working in his laboratory on the previous day. Born in Berlin and educated at the College Royal Français, he studied at the Universities of Freiburg im Breisgau, Berlin, Würzburg, Leipzig and Strasbourg, and took the degrees of Ph.D. in 1902 and M.D. in 1905 at Strasbourg. During 1905-7 he was a member of the staff- of the Institute of Physiological Chemistry in the University of Strasbourg. There he worked under Prof. Franz Hofmeister, to whose influence he attributed much of the success of his career and in whose laboratory he acquired his characteristic meticulous care in all matters of practical technique in the highest tradition of the German school. In 1907 he went to Berlin as head of the Department of Physiological Chemistry at the First Medical Clinic of the Charité, with the title of professor in the Medical Faculty of the University. During the First World War, he directed (1915-18) the Bacteriological Laboratory of the German Army in Brussels. In 1930, he went to Moscow as professor of biochemistry but left after six weeks. He then went to Basle and worked at the Institute of Physiological Chemistry of the University.

In 1932 Friedmann came to Britain to work in the Department of Biochemistry in Cambridge with Sir Frederick Gowland Hopkins. Shortly afterwards his wife was taken seriously ill and died after a long illness, during which everyone was most impressed by his devotion to her. He remained in Cambridge not only because the political conditions in Germany made it impossible for him to return, but also because he had found a congenial atmosphere in Cambridge where Sir Frederick Gowland Hopkins had befriended him and encouraged him to continue to work in his Department. In 1941 he joined a research team engaged in work of national importance for the Agricultural Research Council. In 1946 he came to the Department of Radiotherapeutics of the University of Cambridge, where he worked until his death.

Friedmann's first paper was published in 1900 and he continued active research from then until the end of his life. Many of his papers are now classical, including two papers, "Über die Konstitution des Cystins" (Bei. chem. Physiologie u. Pathologie, 3, $1-46$; 1902), and "Die Konstitution des Adrenalins", (Bei. chem. Physiologie u. Pathologie, 8, 95-120; 1906). He then wrote a series of twenty-five papers under the general title "Zur Kenntnis des Abbaues der Karbonsäure im Tierkörper" published between 1908 and 1914 in the Beiträge zur chemischen Physiologie $u$. Pathologie, which during this time became the Biochemische Zeitschrift. Among his other earlier papers, Dr. Friedmann regarded as the most important those dealing with the constitution of mercapturic acids, the synthesis of isoleucine, the synthesis of surinamine and the formation of ketone bodies.

In Cambridge he started to publish papers on the chemistry of cestrogenic substances. The first of these was a letter in Nature $(135,622 ; 1935)$. At the same time his interest in sulphydryl compounds first appeared. His book entitled "Sterols and Related Compounds" arose from three lectures which he had given at the Institute of Biochemistry in
Cambridge and was published in 1937. These lectures and the book had a great influence.

It was characteristic that Friedmann always kept in touch with the most recent work and modern approach and methods, as exemplified by his studies of radioactive organic bromo-compounds published in collaboration with A. K. Solomon and N. T. Werthessen in 1939. At that comparatively early stage he had already perfected methods for labelling organic compounds with radioactive halogens and advocated their use in biological research. Since 1946 he has published an interesting series of papers on anti-mitotic agents, particularly of the quinone series, which as a rule were tested on tissue culture. These papers were mainly written in collaboration with Mrs. I. Simon-Reuss and Dr. D. H. Marrian.

Most of us knew him only after he came to Cambridge; but we soon saw in him not only a great scientist but also a man of wide cultural background. Brought up in Berlin as the son of a wealthy banker during an era which was famous for its gracious living, he had a great appreciation of beautiful things. His main interests, outside his work, were books, antique furniture and Chinese art, and concerning these he had a tremendous fund of knowledge. He also liked to read detective stories when he felt too tired to work at night. Life had dealt him disappointments, but he never complained and never became embittered. His old-world courtesy was one of his most charming assets. He was always especially kind to younger workers, and never hesitated to spend a great deal of time discussing their work and helping them with their problems from his vast experience and enormous knowledge. He died in harness and, to judge by the vast amount of unpublished experimental data which he left, as active as ever. He leaves a host of friends who will cherish his memory. J. S. Mitcheli

\section{Mr. T. D. Bourdillon}

Thomas Duncan Bourdillon met his death on July 29 while climbing in the Swiss Alps. He had established a world-wide reputation both for his skill as a mountaineer and his more specialized achievements in the art of rock climbing. Through the writings of others he became well known to the general public as a member of several Himalayan expeditions, of which the last was the successful one led by Sir John Hunt in 1953. His contribution to this success lay not only in his inclusion as one of the strongest members of the climbing party, but also in his preparatory researches and development work on the oxygen equipment used, which has been described in the Proceedings of the Royal Society, B, 143, and in the Alpine Journal, 59.

From Gresham's School, Holt, Bourdillon went up to Balliol College, Oxford, in 1942, and was in residence there until June 1944 , at which time he joined the Army. From then until April 1948 he served in Greece and Egypt, and returned to Oxford in October 1948, where he read the honours course in physics and received his degree in June 1950. On coming down from Oxford he joined the Ministry of Supply and was appointed as an experimental officer to the Royal Aircraft Establishment, Westcott, where 
he worked on problems connected with rocket propulsion.

During 1951, 1952 and 1953, he was given leave of absence, to participate in the two preparatory Himalayan Expeditions which culminated in the successful one in 1953. Since that time he has been engaged fully on his rocket work and has made a notable contribution to our understanding of the phenomena of combustion of solid propellants. Although primarily a skilled experimental physicist, he possessed considerable practical engineering ability which stood him in good stead when acting as project officer responsible for the overall development of particular rocket motors. His work at Westcott portrays those innate characteristics which were so ably demonstrated in his mountaineering achievements, namely, scrupulous attention to detail, careful deduction and intellectual honesty.

No doubt Bourdillon will be remembered as a mountaineer first and foremost; but among his colleagues at Westcott there will remain the respect for a man of great personal integrity and a genuine modesty.

He leaves a widow, Jennifer, who shared fully his interests in mountaineering, and two young children. J. E. P. DUnNING

\section{Mr. and Mrs. John Nicol}

Mr. JoHN NiCOL, officer-in-charge of the Ibadan Sub-station of the West African Cocoa Research Institute, died from injuries received in the air disaster at Kano, Northern Nigeria, on June 24; his wife, Mrs. Bessie Nicol, was killed instantly. They were travelling on leave and to a re-union with their only child, Sheila, who is at school in Scotland.

The details of Nicol's complete career at present, available to his colleagues in West Africa are meagre; but records reveal that he was born in 1911 and he graduated at the University of Aberdeen with a B.Sc. degree in forestry. After working for some years with the Department of Scientific and Industrial Research in the United Kingdom on the pests of stored products, he came out to the West African Cocoa Research Institute, Gold Coast, a few weeks after its inception in 1944. He was afterwards promoted to senior entomologist and was posted as officer-in-charge of the sub-station in Nigeria of the Institute in December 1954.

John Nicol's early work in West Africa was concerned with measures for the control of cacao capsids. Later, he became associated with trials concerned with the possibilities for controlling the spread of cacao swollen shoot virus by attack on the mealybug vectors with systemic insecticides.

As a founder member of the staff, John Nicol had much to do with fostering the social life at Tafo, and with these activities, later extended to Ibadan, Bessie Nicol must be closely identified. The construction of the club, the tennis courts and the golf course (the latter being coupled with a malaria-control project) were all, in considerable measure, due to his enthusiasm.

'Nick', as he was widely known, was a talented photographer, his ability being recognized by election to the associateship of the Royal Photographic Society. Many of his photographs of cacao, its pests and its diseases have been published in technical papers by himself or his colleagues.

As officer-in-charge of the Ibadan Sub-station, John Nicol was faced with many difficulties. His gift for making friends and marshalling facts into convincing arguments enabled him to make considerable progress in establishing and equipping a new laboratory and staff accommodation. His untimely death is a severe blow to the progress of cacao research in Nigeria.

JAMES LAMB

\section{NEWS and VIEWS}

Physical Chemistry in the University of Sydney: Prof. A. E. Alexander

Prof. A. E. Alexander has been appointed professor of physical chemistry in the University of Sydney. Prof. Alexander was educated in the Universities of Reading and Cambridge. He began research in Cambridge in association with Sir Eric Rideal and quickly became well known for his contributions to surface and colloid chemistry. During 1939 he worked with Prof. T. Teorell, of Upsala, with a Rockefeller travelling fellowship. On his return to Cambridge he became a Fellow of King's College and, in 1944, assistant director of research in the School of Colloid Science. Prof. Alexander went to Sydney in 1949 as the foundation professor and head of the School of Applied Chemistry in the New South Wales University of Technology, in which he is now dean of the Faculty of Science. He has taken a full part in the scientific life of Australia, having been president of the New Scuth Wales Branch of the Royal Australian Chemical Institute, and of the Sydney University Chemical Society. He is a trustee of the Australian and New Zealand Association for the Advancement of Science, which selected him as the Liversidge Lecturer for 1954, and one of the two representatives in Australia of the Chemical Society of London. He has established excellent relations with the Commonwealth Scientific and Industrial Research Organization and Australian chemical industry. Prof. Alexander's many research papers and books on surface and colloidal science have brought him well-deserved international recognition. His present range of scientific interests-the pure physical chemistry of problems underlying various biological actions-will add welcome strength to the University of Sydney.

\section{Electronics in Armament Research and Develop- ment : \\ Mr. E. W. Chivers}

Mr. E. W. ChIvers, who has been appointed principal superintendent of the Electronics Division of the Armament Research and Development Establishment, graduated in physics (special) with honours in 1927 at Queen Mary College, London. After a short period of postgraduate research, he entered Government service in 1928 and went to the Research Department, Woolwich, where he was engaged on acoustical research in connexion with sound ranging. In 1931 he was transferred to the Searchlight Department at the Air Defence Experimental Establishment, Biggin Hill. His work there was concerned with physical problems associated with searchlights and 